\title{
Will investors return to biotechnology?
}

Venture capital fundraising maintains record levels, according to Daniel Case, chair and CEO of Hambrecht \& Quist, at the 17th Annual Healthcare Conference last month. But with over $50 \%$ of US biotechnology companies operating with only two years cash or less, why isn't this funding going to middlestage biotechnology companies?

"1998 probably had the most prominent number of bankruptcies that I've ever seen in the business," says Hugh Rienhoff of Kiva Genetics (Mountain View, CA). Progenitor, for example, is holding an auction of its Mercator Genetics and Progenitor assets (see p. 119), he says, and this is happening more and more.

In the past, Rienhoff says, mezzanine financiers could expect a company to go public within 12 to 24 months of financing. "That's no longer the case." And because there are no public offerings, mid-stage biotechnology companies have become perpetual mezzanine companies, requiring round after round of private financing. "This idea of just raising money continuously for the purpose of drug discovery and development is really going out of favor [with investors]," says Rienhoff.

As a result, investors are "favoring companies that can generate near-term revenue." Such companies include internet and other computer technology companies that make quick returns. "The only thing that will drive those kinds of investments [in biotechnology] is when the technology is really clearly differentiated and delivers on the early promise of biotech-faster, better, cheaper."

To account for the number of companies struggling at a time of high venture capital, Stefan Ryser of International BioMedicine Investments (Basel, Switzerland) suggests that many biotechnology companies simply do not have the right business strategy to survive. He emphasizes that there is enough funding in the US for those mid-stage companies "that have good technology, product candidates, management team, and potential alliances." However, he points out it will take an increasingly savvy investor to distinguish good from bad. Money from BioMedicine in recent months "happens to be mostly mezzanine financing," says Ryser, citing investments in Exelixis, Telik, Scriptgen, and Intrabiotics as examples, although BioMedicine's strategy is slanted toward emerging technology investments.

So is the situation any different in Europe? "There is plenty of money available in Europe for mid-stage funding," says Paul Haycock of Apax Partners (London), which is closing a $\$ 2$ billion ( $\mathrm{h} 1.8$ billion) invest- ment fund aimed at early-, middle-, and late-stage companies, including health care and biotechnology.

But John Sime, CEO of the BioIndustry Association (London), is not confident that maturing companies in Europe will actually get their next rounds of funding. "There have been a lot of companies, such as PPL [Therapeutics], that have had to go out and make private placements of shares at relatively disadvantageous terms to "tide them over," says Sime, "It is a reflection that money is acutely scarce."

According to Sime, there is simply not enough money to fund all the companies that are looking for it. "I suspect that what we'll see is a move towards consolidation," says Sime, suggesting that the financial markets and institutional investors, as a condition of funding, will try to bring a number of narrowly focused companies with similar or overlapping interests together to make a smaller number of companies that are broader based and, therefore, less risky and more viable.

"What is interesting is the extent to which European investors are investing in US biotech," says Ryser, pointing out that the BioMedicine shareholder base is almost $100 \%$ Swiss institutional investors but that its major share of investments is in the US. Ryser thinks this trend will change but, for now, companies in the US have more experienced management teams and better access to the pharmaceutical industry and therefore more likely to form alliances.

However, according to David Stone, analyst at S.G. Cowen Securities (New York), "A
US investor who wouldn't look at some of the US offering may well consider an Easdaq/Nasdaq security, expecting the stock to perform well." $\mathrm{He}$ points out that biotechnology deals have continued to get done in Europe while the window's been shut in the US. "Europe is the one bright spot on this."

It remains unclear whether financiers will increase their funding of mid-stage biotechnology companies. "Whether institutional investors continue to back the biotech industry in preference to perceived easier pickings in high tech is really an open question," says Simon Waddington of PolyTechnos Venture-Partners (Frankfurt, Germany).

Although Rienhoff remains "skeptical that [investment in biotech in the US] will come back in a general way," Stone says "We're optimistic that '99 will be a better year. . for biotech in particular." He adds that "There's a good load of progress on the product development and FDA approval side," suggesting that this will be sufficient to attract financing again.

In 1996 and 1997, Ryser points out, 10\% of pharmaceutical product launches were attributable to the biotechnology industry, whereas in 1998 , it was $25 \%$. This, he says, indicates that there are now more biotechnology companies producing products (and that are therefore profitable), and that the research-based pipeline gap is beginning to be filled with biotechnology companies. "I am convinced that biotech is still and will be attractive to investors," says Ryser.

Emma Dorey

\section{Asthma targets: Research dilemma}

Two developments in identifying targets for asthma drug discovery have highlighted the precarious nature of focused drug development efforts. Last month, Magainin Pharmaceuticals (Plymouth Meeting, PA) announced a research agreement with Genentech (South San Francisco, CA) to develop asthma treatments targeting the IL-9 pathway. This followed a report (Science 282:2258-2262, 1998) that pointed to two other interleukin molecules, IL4 and IL-13, as possible asthma drug targets. In the face of large population genetics studies being conducted by companies like Glaxo Wellcome (London), however, such efforts begin to look piecemeal.

Asthma affects over 13 million people in the US alone-clearly a big market opportu- nity - and the identification of targets is a key part of drug development. Researchers had been looking at IL-4 and IL-13 in connection with asthma for some time. Both bind to the same receptor complex, but it had previously been thought that it was IL-4 that was principally responsible for inducing inflammation in asthma.

Then scientists at Genetics Institute (Cambridge, MA) discovered another receptor that binds to IL-13, but not IL-4. In experiments with mice, they made the surprising discovery that a soluble version of the new IL-13 receptor could block the induction of asthma, probably by binding excess IL-13 in the bloodstream and cutting off the asthma-inducing signal. 